\title{
The smaller vesicomyid bivalves in the genus Isorropodon (Bivalvia, Vesicomyidae, Pliocardiinae) also harbour chemoautotrophic symbionts
}

\author{
Clara F. Rodrigues - Marina R. Cunha - Karine Olu • \\ Sébastien Duperron
}

Received: 9 March 2012 / Accepted: 11 May 2012 / Published online: 25 May 2012

(C) Springer Science+Business Media B.V. 2012

\begin{abstract}
Species of Isorropodon are vesicomyid bivalves for which little information is available regarding host phylogeny and bacterial symbioses. In this study we investigated the symbioses in three Isorropodon species from three cold seep areas: Isorropodon bigoti (Gulf of Guinea), Isorropodon megadesmus (Gulf of Cadiz) and Isorropodon perplexum (Eastern Mediterranean). Analysis of bacterial 16S ribosomal RNA gene sequences demonstrated that each vesicomyid species harbours a single symbiont phylotype, that symbionts from the three species cluster together, and that they are closely related to other known vesicomyid symbionts. These results are confirmed by other marker genes (encoding 23S rRNA and APS reductase) and by fluorescence in situ hybridization. Due to their extended depth range and transoceanic distribution Isorropodon species are interesting examples to further study evolutionary processes in bivalve hosts and their associated symbionts.
\end{abstract}

Keywords Vesicomyids · Isorropodon · Symbioses ·

Reduced environments $\cdot$ Atlantic $\cdot$ Mediterranean

\section{F. Rodrigues $\cdot$ S. Duperron}

Université Pierre et Marie Curie, UMR 7138 (UPMC CNRS IRD

MNHN), Systématique, Adaptation, Evolution,

7, quai St. Bernard, bâtiment A,

75005 Paris, France

C. F. Rodrigues $(\square) \cdot M$. R. Cunha

Departamento de Biologia \& CESAM, Universidade de Aveiro,

Campus Universitário de Santiago,

3810-193 Aveiro, Portugal

e-mail: clara.rodrigues@ua.pt

K. Olu

Laboratoire Environnement Profond, Département Etudes des Ecosystèmes Profonds, Centre Ifremer de Brest,

BP 71, 29280 Plouzané, France

\section{Introduction}

Vesicomyidae clams are among the dominant metazoan fauna in deep-sea sulphide-rich habitats (e.g. hydrothermal vents, cold seeps, whale carcasses) and occur worldwide from $77^{\circ} \mathrm{N}$ to $70^{\circ} \mathrm{S}$ at depths from 100 to $9,050 \mathrm{~m}$ (Krylova and Sahling 2010). Genera within the subfamily Pliocardiinae (considered large-sized vesicomyids, with shell lengths in the range of 1 to $30 \mathrm{~cm}$ ) display distinctive shared features including reduced gut and feeding groove, indicating a large dependence upon (intracellular) chemoautotrophic bacteria for their nutrition (Krylova and Sahling 2010). Indeed all large-sized vesicomyids studied so far live in obligate symbiosis with sulphur-oxidising Gammaproteobacteria located within their gill epithelial cells, and data regarding the diversity, structure and functioning of symbioses have been published by several authors (see Kim et al. 1995; Imhoff et al. 2003; Hurtado et al. 2003; Stewart et al. 2008; Stewart and Cavanaugh 2009; Stewart et al. 2009). The advent of symbiosis in this group is probably linked to its radiation that started in Eocene (from about 55 MYA) (Amano and Kiel 2007). Unlike most chemosynthetic symbioses found in metazoan, the transmission of bacterial symbionts from one generation to the next in vesicomyids is predominantly vertical, although occasional acquisition of alternative lineages from the environment is also documented (Cary and Giovannoni 1993; Dubilier et al. 2008; Stewart et al. 2008). Vertical transmission in vesycomyids leads to host/symbiont co-speciation patterns which are not observed for example in mytilids, despite the close relatedness of sulphur-oxidising symbionts in these two bivalve families (Peek et al. 1998). Genome sequencing of symbionts has emphasized several traits typical of maternallytransmitted bacteria, including genome size reduction coupled with the loss of certain genes (Kim et al. 1995; Harada 
et al. 2009; Kuwahara et al. 2008; Stewart et al. 2008). The systematics and evolution of Pliocardiinae hosts have also been studied but their taxonomy is still under debate as genera are typically found non-monophyletic in phylogenetic reconstructions (Kojima et al. 1995; Baco et al. 1999; Osborn 2001; Goffredi et al. 2003; Kojima et al. 2004, 2006; Decker et al. 2012). Yet, apart from large-sized Pliocardiinae vesicomyids, there are in this subfamily smaller-sized species which have been overlooked, and for which very little data is available, both for hosts and associated symbionts. Among these, the genus Isorropodon includes nine accepted species reported from the Eastern Atlantic Ocean along the west coast of Africa from Namibia to Mauritania (Isorropodon bigoti Cosel and Salas 2001, I. curtum Cosel and Salas 2001, I. megadesmus Oliver et al. 2011, I. striatum (Thiele \& Jaeckel, 1931) and I. tenina (Allen, 2001)), the Southern and North Western Atlantic basins (I. elongatum (Allen, 2001)), the Eastern Mediterranean Sea (I. perplexum,Sturany, 1986 the type species), the Norwegian Sea (I. nyeggaensis Krylova et al. 2011) and the Japan and Aleutian Trenches (I. fossajaponicum Okutani et al. 2000) (see for review Krylova et al. 2011; Oliver et al. 2011). The vertical range of Isorropodon is very broad, extending from $150 \mathrm{~m}$ to $6,809 \mathrm{~m}$ and the genus has been found in several habitats including oil drilling platform areas, soft mud, vegetal debris and mud volcanoes (Krylova and Sahling 2010; Krylova et al. 2011). Transmission electron micrographs of Isorropodon perplexum gill tissue showed the presence of bacteriocytes enclosing sulphur-oxidising bacteria (Olu-Le Roy et al. 2004). The thick and large gills of I. bigoti and I. megadesmus suggest that these species also harbour bacteria (Cosel and Salas 2001; Oliver et al. 2011) although these were not yet identified. In addition, carbon and sulphur stable isotope signatures ( -31 and $-1 \%$, respectively) in Isorropodon perplexum tissues indicate that thiotrophy may significantly contribute to their nutrition (Olu-Le Roy et al. 2004; Carlier et al. 2010). The only available molecular data for symbiotic bacteria are from the abundant endosymbionts occurring in the gills of I. fossajaponicum (initially ascribed to the genus Calyptogena) from the Japan Trench (Okutani et al. 2000; Fujiwara et al. 2000). Recently, we recovered a few specimens of three Isorropodon morphospecies from the Eastern Mediterranean, Gulf of Cadiz and Gulf of Guinea cold seeps. In order to verify the monophyly of Isorropodon, we sequenced cytochrome oxidase I (COI), a molecular marker previously used in vesicomyid studies (Baco et al. 1999; Peek et al. 1997; Goffredi et al. 2003; Decker et al. 2012). In order to characterize potential bacterial partners associated with Isorropodon species, we used comparative 16S rRNA gene sequence analysis and fluorescence in situ hybridization (FISH). Because 16S rRNA displays notably low variation among vesicomyid symbionts (Stewart et al. 2008, 2009), we also sequenced fragments of the 23S rRNA- and adenosine 5'phosphosulfate (APS) reductase-encoding genes, to better assess the level of relatedness to other vesicomyid symbionts. This work presents the first molecular characterization of Atlantic Isorropodon vesicomyids and their associated symbionts. Because of their transoceanic and vertical distribution, Isorropodon clams may provide good models for further studies of host/symbiont biogeography and evolution.

\section{Material and methods}

\subsection{Specimens}

The specimens analysed belong to three Isorropodon morphospecies from three distinct sites: Isorropodon bigoti (Gulf of Guinea), Isorropodon megadesmus (Gulf of Cadiz) and Isorropodon perplexum (Eastern Mediterranean) (Fig. 1a). Three specimens of Isorropodon bigoti were collected at cold seeps on a pockmark at the Guiness Site (Gulf of Guinea, cruise WACS, ROV dive $433,1^{\circ} 34.65^{\prime} \mathrm{S}, 8^{\circ} 32.91^{\prime} \mathrm{E}, 582 \mathrm{~m}$ depth). Morphologically similar to I. perplexum, I. bigoti is distinguished by its larger size, the much less visible and more spaced growth lines and the more conspicuous wavy pattern of growth (Cosel and Salas 2001). This species was initially collected in an oil field at $150 \mathrm{~m}$ off Congo and deeper near Mauritania at $900-1,200 \mathrm{~m}$. It was further sampled in a methane hydrate area in the Congo basin (500-800 m depth), (Cosel and Olu 2009). A single specimen of I. megadesmus was collected at the Darwin Mud volcano (Gulf of Cadiz, cruise TTR17, station AT664Gr, $35^{\circ} 23.52^{\prime} \mathrm{N}, 07^{\circ} 11.48^{\prime} \mathrm{W}$, $1,128 \mathrm{~m}$ depth). This species is characterized by its large ligament that rises well above the dorsal margin of the shell and extends posteriorly beyond the nymph to fill the escutcheon and was previously reported only for Captain Arutyunov mud volcano (Oliver et al. 2011). Three specimens of $I$. perplexum were collected at the Amsterdam mud volcano (Eastern Mediterranean, Cruise MSM13/4, Station MSM13/

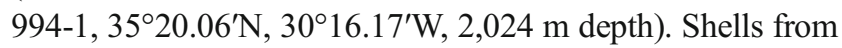
this species are thin-walled, ovate to elliptical in outline, with prosogyrate beaks. The escutcheon is present and lunular incision indistinct or missing (Cosel and Salas 2001).

The specimens were dissected immediately following collection and their gills were preserved for symbiont characterization using molecular and fluorescent in situ hybridization. Shells were kept for morphological comparison with documented species.

2.2 DNA extraction, polymerase chain reaction, and sequencing

Total DNA was extracted from ethanol-preserved gill tissue of all specimens using the DNeasy Blood and Tissue Kit (QIAGEN, CA, USA). A fragment of mtCOI and of three bacterial genes (16S ribosomal RNA (rRNA), 23S rRNA 
Fig. 1 Isorropodon species of this study. Map with sampling locations (a). ML phylogenetic tree based on the mitochondrial COI gene of vesicomyids (515 bp) (b). Scale bar represents estimated $5 \%$ sequence substitution. Bootstrap support values over $50 \%$ are shown. Taxonomy according to the WORMS database as of $01 / 03 / 2012$ (GENBANK name also included; in grey). Species studied herein are represented in red, EM: Eastern Mediterranean; GoC: Gulf of Cadiz and GoG: Gulf of Guinea

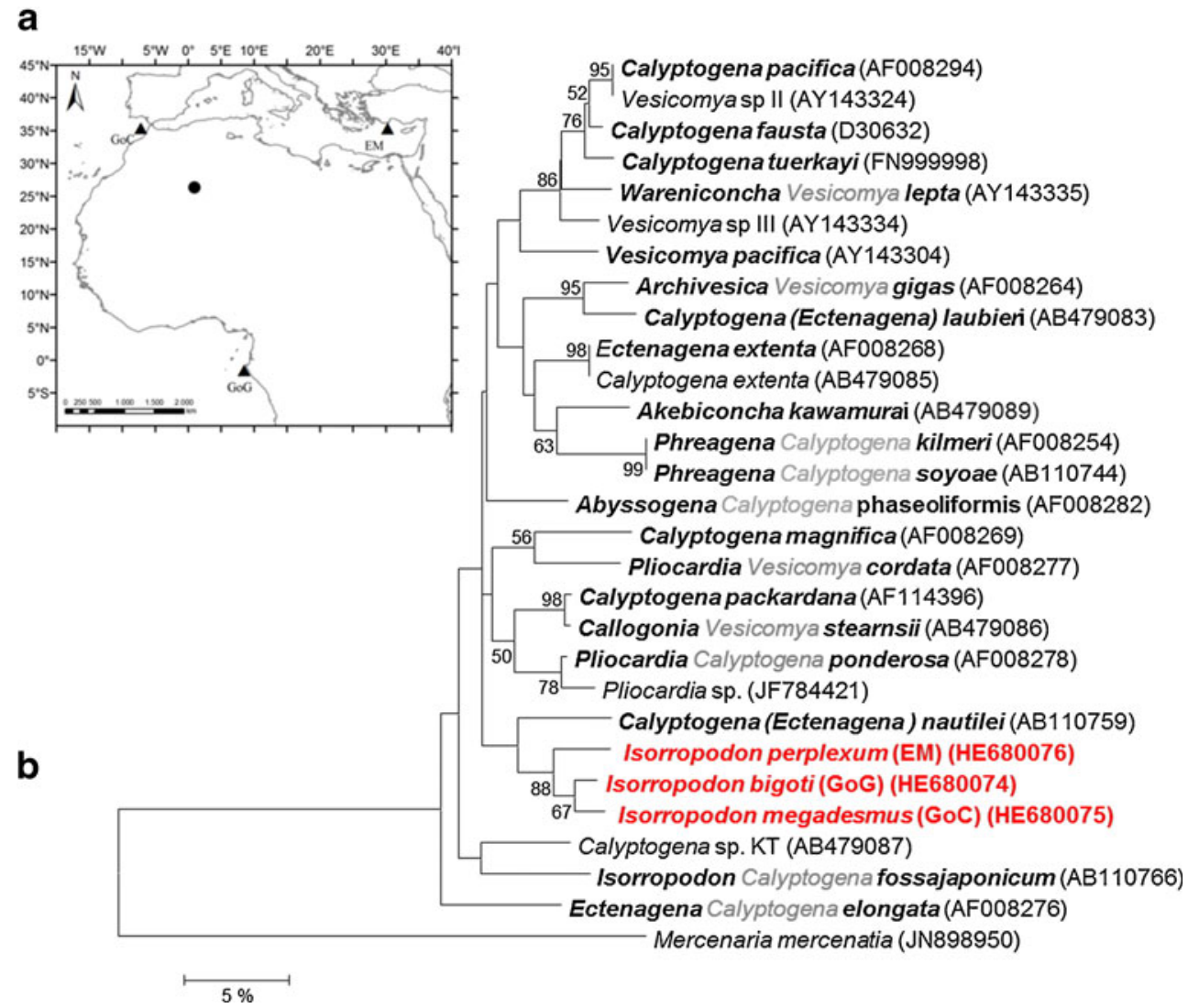

and APS reductase) were amplified from all specimens (see Table 1 for PCR details).

For mtCOI, 23S rRNA and APS reductase amplification, products were purified using a gel extraction kit (QIAGEN) and were sequenced at GATC Biotech (Constanz, Germany). For each species, a $16 \mathrm{~S}$ rRNA gene library was constructed from three independent PCR products of each individual clam, that were pooled, cleaned using a QIAquick Kit (QIAGEN) and cloned (TA ${ }^{\mathrm{TM}}$ cloning kit with $\mathrm{pCR}^{\circledR}$ TOPO 2.1. vector, Invitrogen, CA, USA). Between 14 and 29 positive clones were selected from each specimen and full-length inserts sequenced. Sequences were checked

Table 1 PCR conditions and primers used in this studyDS: amplification products were purified and sequenced directly. GL: a gene library was constructed

\begin{tabular}{|c|c|c|c|c|c|}
\hline Gene & Gene-length & Primers $\left(5^{\prime}>3^{\prime}\right)$ & PCR conditions & Reference & \\
\hline $\mathrm{COI}$ & $\begin{array}{l}\text { Mitochondrial } \\
\text { gene- }-560 \mathrm{nt}\end{array}$ & $\begin{array}{l}\text { VesLCO -TTAATAGGAA } \\
\text { CTGCTTTTAG } \\
\text { VesHCO -TCACCCAAACC } \\
\text { AGCAGGATC }\end{array}$ & $\begin{array}{l}35 \text { cycles of } 30 \mathrm{~s} @ 94{ }^{\circ} \mathrm{C}, 60 \\
\mathrm{~s} @ 45{ }^{\circ} \mathrm{C} \text {, and } 75 \mathrm{~s} @ 72{ }^{\circ} \mathrm{C}\end{array}$ & Peek et al. 1997 & DS \\
\hline $16 \mathrm{~S}$ & $\begin{array}{l}\text { Small subunit } \\
\text { rRNA- 1500nt }\end{array}$ & $\begin{array}{l}27 \text { F - AGAGTTTGATC } \\
\text { (AC)TGGCTAG } \\
\text { 1492R - ACGG(CT)ACCTT } \\
\text { GTTACGACTT }\end{array}$ & $\begin{array}{l}24 \text { cycles of } 45 \mathrm{~s} @ 94{ }^{\circ} \mathrm{C} \text {, } \\
45 \mathrm{~s} @ 45^{\circ} \mathrm{C} \text {, and } 105 \\
\mathrm{~s} @ 72{ }^{\circ} \mathrm{C}\end{array}$ & Lane 1991 & GL \\
\hline $23 \mathrm{~S}$ & $\begin{array}{l}\text { Large subunit } \\
\text { rRNA- } 900 \mathrm{nt}\end{array}$ & $\begin{array}{l}3505 \text { F - GACCGTCAGCTAA } \\
\text { GGTCCCAA } \\
\text { 4761R -CCAGTCAAACTACCCAC } \\
\text { CATG }\end{array}$ & $\begin{array}{l}35 \text { cycles of } 45 \mathrm{~s} @ 94{ }^{\circ} \mathrm{C}, 45 \\
\mathrm{~s} @ 53{ }^{\circ} \mathrm{C} \text {, and } 2 \min @ 72{ }^{\circ} \mathrm{C}\end{array}$ & Stewart et al. 2009 & DS \\
\hline APS & $\begin{array}{l}\text { adenosine } \\
\text { 5'-phosphosulfate } \\
\text { reductase - } \\
\sim 390 \mathrm{nt}\end{array}$ & $\begin{array}{l}\text { AprA-1-FW - TGGCAGATCATGA } \\
\text { TYMAYGG } \\
\text { Apar1-5-RV - GCGCCAACY } \\
\text { GGRCCRTA' }\end{array}$ & $\begin{array}{l}32 \text { cycles of } 1 \text { min } @ 92{ }^{\circ} \mathrm{C}, \\
1 \text { min@ } 58{ }^{\circ} \mathrm{C} \text {, and } \\
1 \text { min@ } 72{ }^{\circ} \mathrm{C}\end{array}$ & Meyer and Kuever 2007 & DS \\
\hline
\end{tabular}


for chimaeras with Chimera Check Ribosomal Database Project II (http://rdp.cme.msu.edu/, Cole et al. 2003), and most similar sequences were identified using Blast (http:// www.ncbi.nlm.nih.gov) (Altschul et al. 1997)

\subsection{Phylogenetic analysis}

Sequence alignments including Blast hits and representative sequences were generated for the mtCOI-, $16 \mathrm{~S}$ rRNA-, the 23S rRNA- and the APS reductase-encoding genes using ClustalX and edited manually (Thompson et al. 1997). Phylogenetic relationships were reconstructed using Maximum Likelihood (ML) with the PHYLIP package (Felsenstein 1993). ML used a transition/transversion ratio of two, empirical base frequencies, no rate variation among sites, and randomized input of sequences. Robustness of clades was evaluated by 100 ML bootstrap replicates. For proteins (APS) ML were analysed using the PROML function with the JTT model for probabilities of change between aminoacids.

16S rRNA was further analysed using Bayesian analysis with Mr. Bayes under a GTR model and Gamma rates run for $4.10^{6}$ generations (discarding $10 \%$ samples as burn-in) (Ronquist and Huelsenbeck 2003). Robustness of clades of bacterial 16S rRNA gene sequences was evaluated by 1,000 ML bootstrap replicates and computation of Bayesian posterior probabilities.

\subsection{Statistical analysis}

Correlation between hosts and symbiont genetic distances, and geographical distances were tested using the Mantel test (PAST, Hammer et al. 2001). Two geographical scenarios were investigated: (1) Great Arc distances between pairs of locations were estimated from the geographical coordinates; and (2) Minimum oceanic distances around continents and islands were estimated using GOOGLE EARTH v.5. The shortest paths between all pairs of locations were traced around present-day continental shelf margins that intervened between locations (Zielinski et al. 2009).

\subsection{Fluorescence in situ hybridization}

Gill tissue was fixed on board using $4 \%$ formaldehyde in filtered seawater for $2 \mathrm{~h}$ at $4{ }^{\circ} \mathrm{C}$, two rinses in filtered seawater and dehydration in increasing ethanol series (50, 80 and $100 \%, 10$ min each). Gills were embedded in PEG distearate: 1-hexadecanol (9:1) wax and cut into 7- $\mu \mathrm{m}$-thick sections using a microtome. Sections were hybridized as previously described using Cy3- and Cy5 labelled probes and a negative control (Duperron et al. 2007). Probe Gam42 (5'- GCCTTCCCACATCGTTT-3') that targets the 23S
rRNA (large subunit) was used to highlight the presence of Gammaproteobacteria, and probe ImedT2-193 (5'TAGAGGCCTCCTTTA-3') that targets the 16S rRNA (small subunit), originally designed for mussel symbionts, was also used here since mussel symbionts are closely related with vesicomyid symbionts. All probes were tested at $30 \%$ formamide. Hybridized sections were observed under an Olympus BX61 epifluorescence microscope (Olympus, Japan).

\section{Results and discussion}

\subsection{Host characterization}

The $560 \mathrm{bp}$ fragments of mtCOI amplified from all specimens of the three Isorropodon morphospecies displayed $90 \%$ similarity with the mtCOI sequence form Calyptogena nautilei (AB110759). COI from I. bigoti (Gulf of Guinea, sequences identical for the three specimens) and I. megadesmus (Gulf of Cadiz) presented $3.4 \%$ sequence divergence whereas the sequences of I. bigoti and I. perplexum (Eastern Mediterranean, sequences identical for the three specimens) presented $7 \%$ divergence. The same level of divergence $(7.5 \%)$ occurred between COI from I. megadesmus and I. perplexum. Phylogenetic analysis indicated that these three Isorropodon morphospecies formed a monophyletic group (Fig. 1b) related to Calyptogena nautilei, but with a low bootstrap support. COI genetic distances did not correlate with geographic distances (Mantel Test, $p>0.6$ ). The two Atlantic species presented higher sequence similarity compared with I. perplexum suggesting the occurrence of a biogeographical barrier. Previous studies on fishes and crustaceans have shown the effect of three putative barriers to gene flow between the Atlantic and the Mediterranean: Strait of Gibraltar, Almeria-Oran Front and Ibiza Channel (Garcia-Merchan et al. 2012). The level of divergence among COI sequences from the three Isorropodon species is within the range of values documented between distinct populations of the species Archivesica gigas which may, in fact, be a species complex (Osborn 2001). Goffredi et al. 2003 study on the "pacificallepta" species documented divergence levels between 0.2 and $2.8 \%$ (intraspecific) and between 3.9 and $10.3 \%$ (interspecific), levels that were consistent with the ones reported for other described species of vesicomyids (Peek et al. 1997, 2000). Baco et al. (1999) and Kojima et al. (2006) documented much lower intraspecific levels of COI variations (from 0.1 to $1.8 \%$ ) in Calyptogena kilmeri, Calyptogena elongata and Calyptogena solidissima. The level of divergence reported here is congruent with inter-specific, rather than intra-specific, variations. Moreover, the three Isorropodon morphospecies displayed distinctive morphological features and we can 
reasonably assume at this stage that they actually represent distinct species.

Overall the Vesicomyidae phylogenetic tree based on COI data displayed low resolution between the various lineages, and genera did not appear monophyletic. For example, Isorropodon fossajaponicum (initially described as Calyptogena fossajaponica) (Okutani et al. 2000), did not branch within the Isorropodon clade (Fig. 1). Since I. perplexum is the type species of the genus, the name should be restricted to the group documented here, but this emphasizes the need for a revision of the whole family, including the use of additional molecular markers. Indeed, because genera were initially poorly defined in Vesicomyidae, recent work has attempted to clarify the taxonomy of the family (see Krylova and Sahling 2010 for review). However the taxonomic and phylogenetic study of this group is still in progress, and the incongruence between clades and named genera is fairly evident from our, as well as from other authors' phylogenies (Peek et al. 1997; Goffredi et al. 2003; Kojima et al. 2004; Decker et al. 2012).

\subsection{Bacterial symbioses in Isorropodon}

A total of 130 clones were analysed from 16S rRNA-based libraries: 24 from I. megadesmus, 48 from the three specimens of I. perplexum, and 58 from the three specimens of $I$. bigoti. A single phylotype was recovered within each of the three species. Sequences for the three species differed from each other by 1.4 to $3 \%$ (Table 2), and displayed over $98 \%$ sequence similarity with other vesicomyid symbionts. Similar levels of divergence (1.7 to $2.8 \%$ ) were also observed among the $23 \mathrm{~S}$ rRNA-encoding gene sequences. APS reductase (encoding a key enzyme of sulphur metabolism) nucleic acid sequences were identical for I. megadesmus and I. perplexum, and both differed by $3.6 \%$ from that of I. bigoti (Table 2).

Table 2 Similarity matrix between symbiont sequences from the three Isorropodon species. Genes encoding 16S rRNA, 23S rRNA and APS are presented

\begin{tabular}{lllcl}
\hline & Host name & I. bigoti & I.megadesmus & I. perplexum \\
\hline \multirow{2}{*}{$16 \mathrm{~S}$} & I. bigoti & 1 & 0.980 & 0.970 \\
& I.megadesmus & - & 1 & 0.986 \\
& I.perplexum & - & - & 1 \\
$23 \mathrm{~S}$ & I. bigoti & 1 & 0.981 & 0.972 \\
& I.megadesmus & - & 1 & 0.983 \\
& I.perplexum & - & - & 1 \\
\multirow{2}{*}{ APS } & I. bigoti & 1 & 0.964 & 0.964 \\
& I.megadesmus & - & 1 & 1 \\
& I.perplexum & - & - & 1 \\
\hline
\end{tabular}

In the 16S rRNA- (Fig. 2a), the 23S rRNA- (Fig. 3a) and the APS-reductase-based trees (Fig. 3b), Isorropodon sequences clustered with other vesicomyid associated symbionts. Trees based on each of the three genes indicated monophyly of the three Isorropodon-associated bacterial sequences, although with low to moderate bootstrap support (54, 88 and 67, respectively). For all genes, genetic distances between symbionts were not correlated both with Great Arc and Minimum oceanic distances (Mantel tests, $p>0.6$ ).

Gill tissue of all specimens of the three species hybridized successfully with the Gammaproteobacteria-specific probe Gam42, and with the probe Imed-T2-193, initially designed for mussel-associated thiotrophs but also targeting vesicomyid symbionts due to closeness between these phylotypes (Duperron et al. 2008). Positive signals were located within a single epithelial cell type occurring in the lateral zone of gill filaments (known as bacteriocytes, Fisher 1990). Signals occupied most of the volume within bacteriocytes indicating very dense symbiont populations in all specimens (Fig. 2b and c). Overall, the smaller Isorropodon species display symbioses resembling those documented in larger vesicomyid species, with dense bacterial populations in the gills. The identification of a sulphur metabolism (APS reductase), the phylogenetic clustering of all vesicomyod symbionts, and the presence of sulphide in the clam's habitat all suggest these symbionts oxidize sulphide like those of larger vesicomyids. Furthermore, the tissue $\delta^{13} \mathrm{C}$ values of $-31.1 \%$ reported for Isorropodon perplexum (Olu-Le Roy et al. 2004) and between -33.1 and $-32.7 \%$ for Isorropodon bigoti suggest that thioautotrophy contributes significantly to the nutrition of the hosts.

\subsection{Host/symbiont relationships and the evolution of Isorropodon}

The monophyly of symbiont sequences mirrors that of their Isorropodon hosts. In the host tree, I. megadesmus and I. bigoti are more closely related, but with low bootstrap support, suggesting that COI does not resolve well withingroup relationships. Altogether our results do not contradict the hypothesis of maternal inheritance and host/symbiont co-speciation postulated for other Vesicomyidae (Peek et al. 1998; Stewart et al. 2008). However, vesicomyid symbionts display highly similar $16 \mathrm{~S}$ rRNA sequences (range: 91.9 to $99.9 \%$; mean: $97.0 \pm 1.4 \%$; $n=26$ sequences ( 23 retrieved from Genbank and three from this study)), which does not allow to resolve symbiont phylogeny properly. Although 23S rRNA is often considered a more variable marker (Stewart et al. 2009), it is only slightly more variable among the 10 available vesicomyid symbiont sequences (range: 91.1 to $99.6 \%$; mean: $94.9 \pm 2.4 \% ; n=10$ sequences $(7$ retrieved from Genbank and three from this study)), and additional markers will be necessary to settle the issue of 
Fig. 2 Phylogenetic tree based on 16S rRNA sequences $(1,267$ positions in the alignment). Scale bar represents estimated $2 \%$ sequence substitution. Values at nodes indicate posterior probabilities (Bayesian/bootstrap values (ML) over $50 \%$ are shown). Sequences in red are from this study. ML and Bayesian analysis yielded identical tree topologies. Host taxonomy according to the WORMS database (GENBANK name also included; in grey). FISH hybridization on Isorropodon bigoti (b) and Isorropodon megadesmus gill transverse sections (c) with the Gam-42 (stained in green) and ImedT2193 (stained in red) with an overlay result (yellow). No signal was observed from the ciliated zones, whereas all bacteriocytes from the lateral zones displayed dense FISH signal (in yellow), indicating bacteriocytes filled with bacteria. Nuclei of vesicomyid cells, which are counterstained with DAPI, appear blue

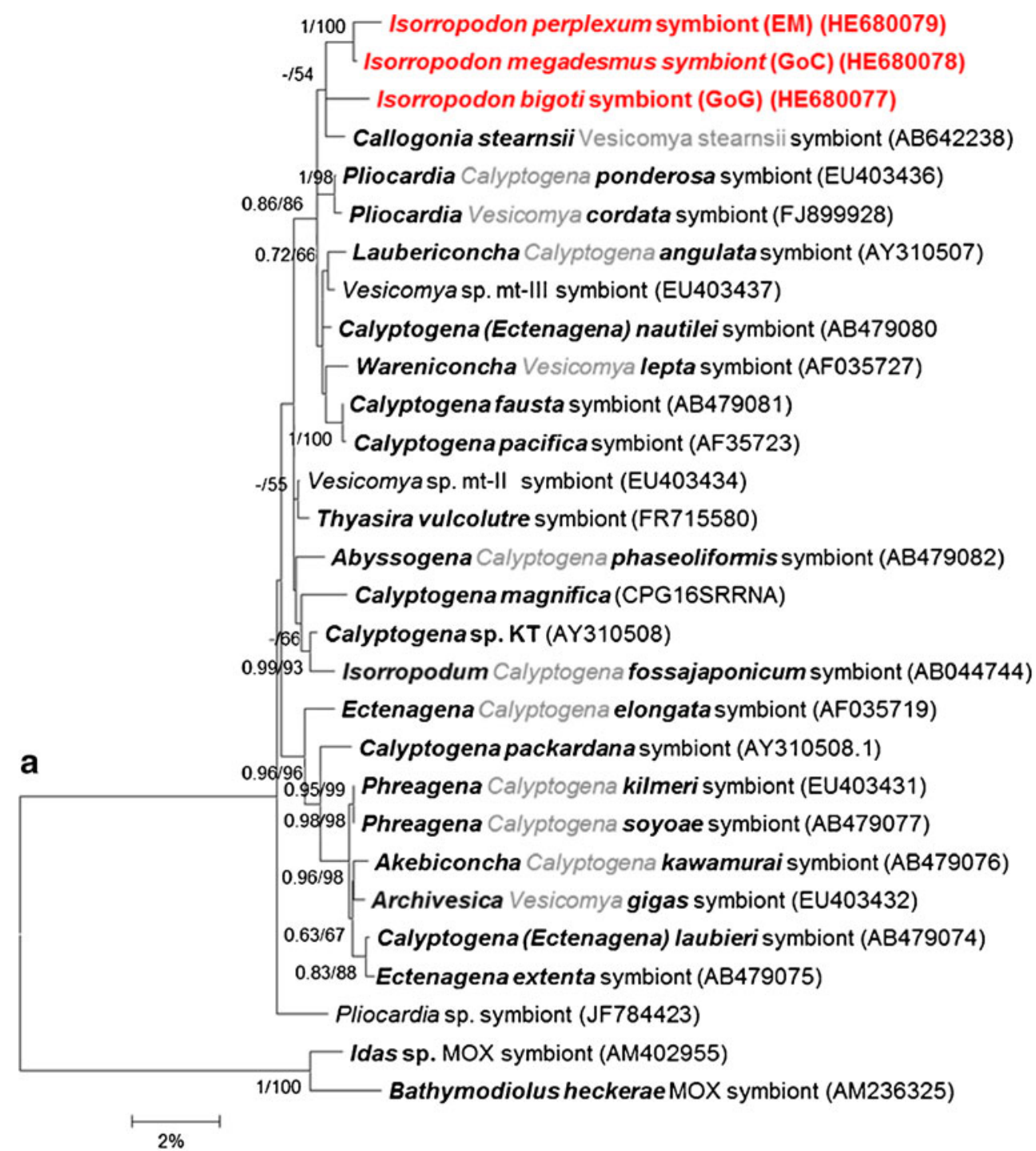

b

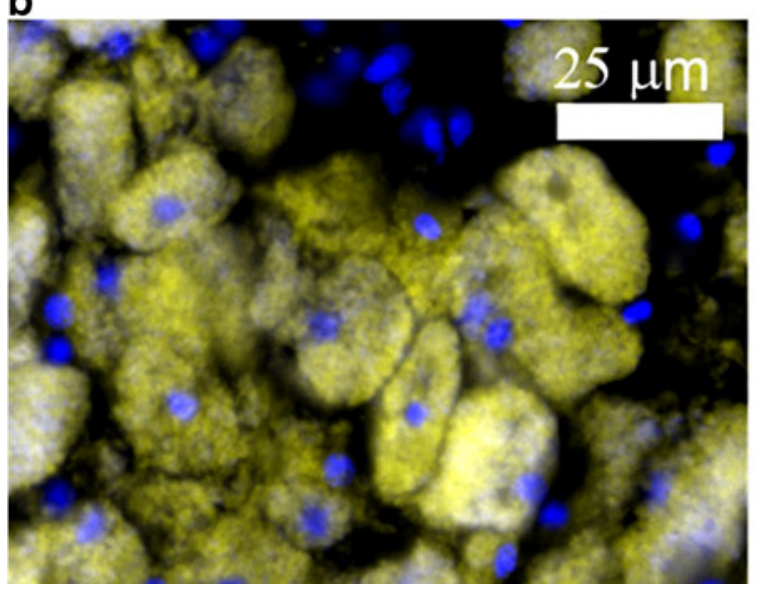

c

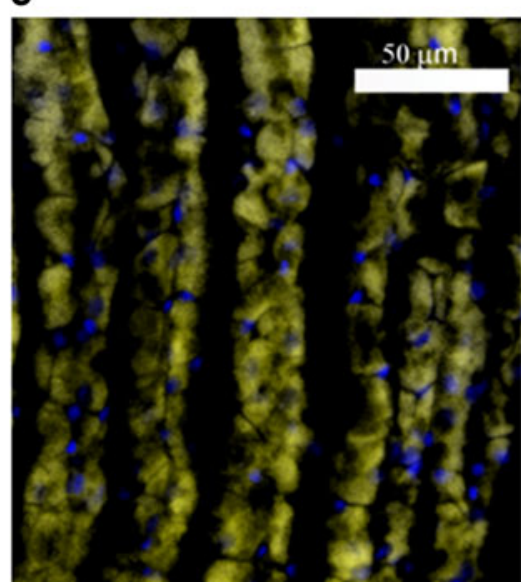

co-speciation. Other vesicomyid species are found in the Eastern Atlantic, but I. perplexum is to our knowledge the only species documented in the Mediterranean. Larger vesicomyids tentatively attributed to the genus Calyptogena were sampled in the Miocene fossil record, together with large Bathymodiolus type mytilids and lucinids (Taviani 1994). Because of episodes such as the Messinian Salinity crisis (5.96-5.33 MYA, Duggen et al. 2003), it can be 
Fig. 3 Phylogenetic trees based on a fragment of the $23 \mathrm{~S}$ rRNA encoding gene (796 positions analysed) (a) and on a fragment of the gene-encoding alpha subunit of APS reductase (125 amino acid positions analysed) (b). Scale bars represent estimated $5 \%$ sequence substitution. For both trees, robustness of clades was evaluated by 100 ML bootstrap replicates. Bootstrap support values over $50 \%$ are shown. Sequences in red are from this study. Host taxonomy according to the WORMS database (GENBANK name also included; in grey) a

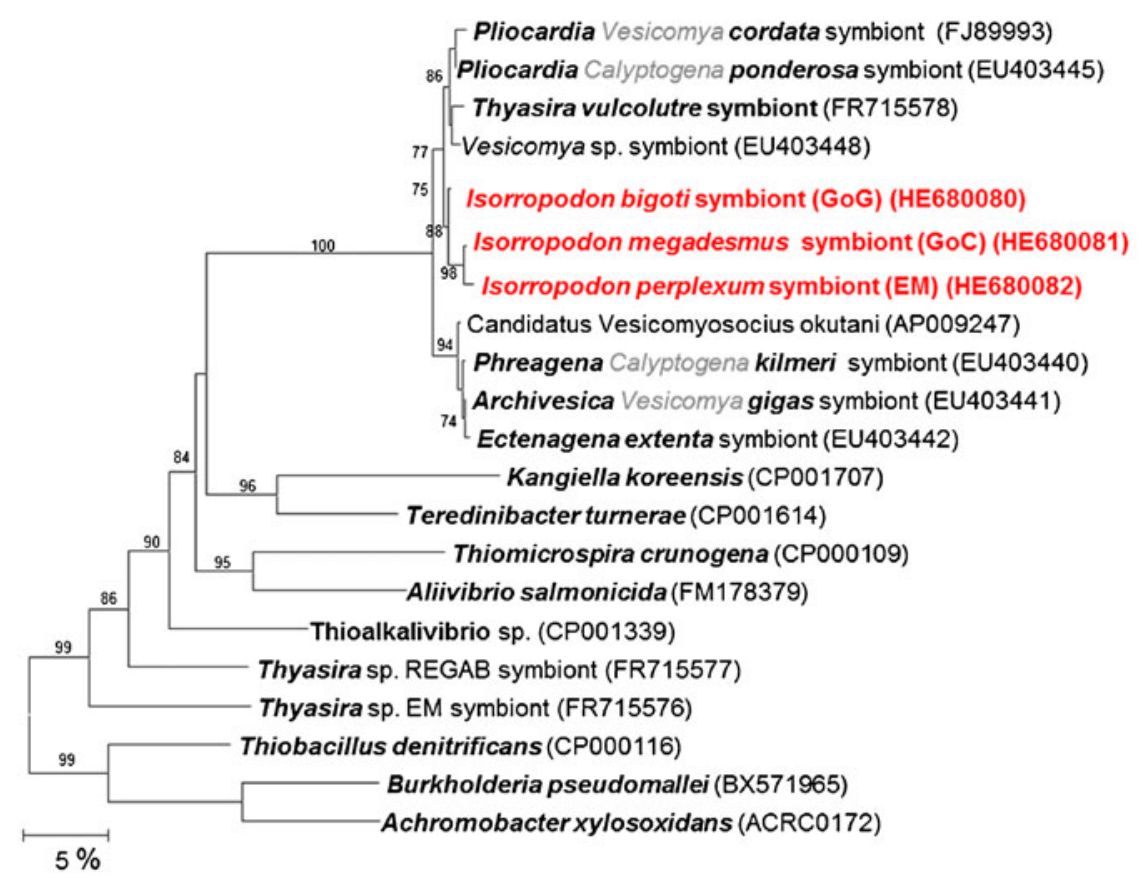

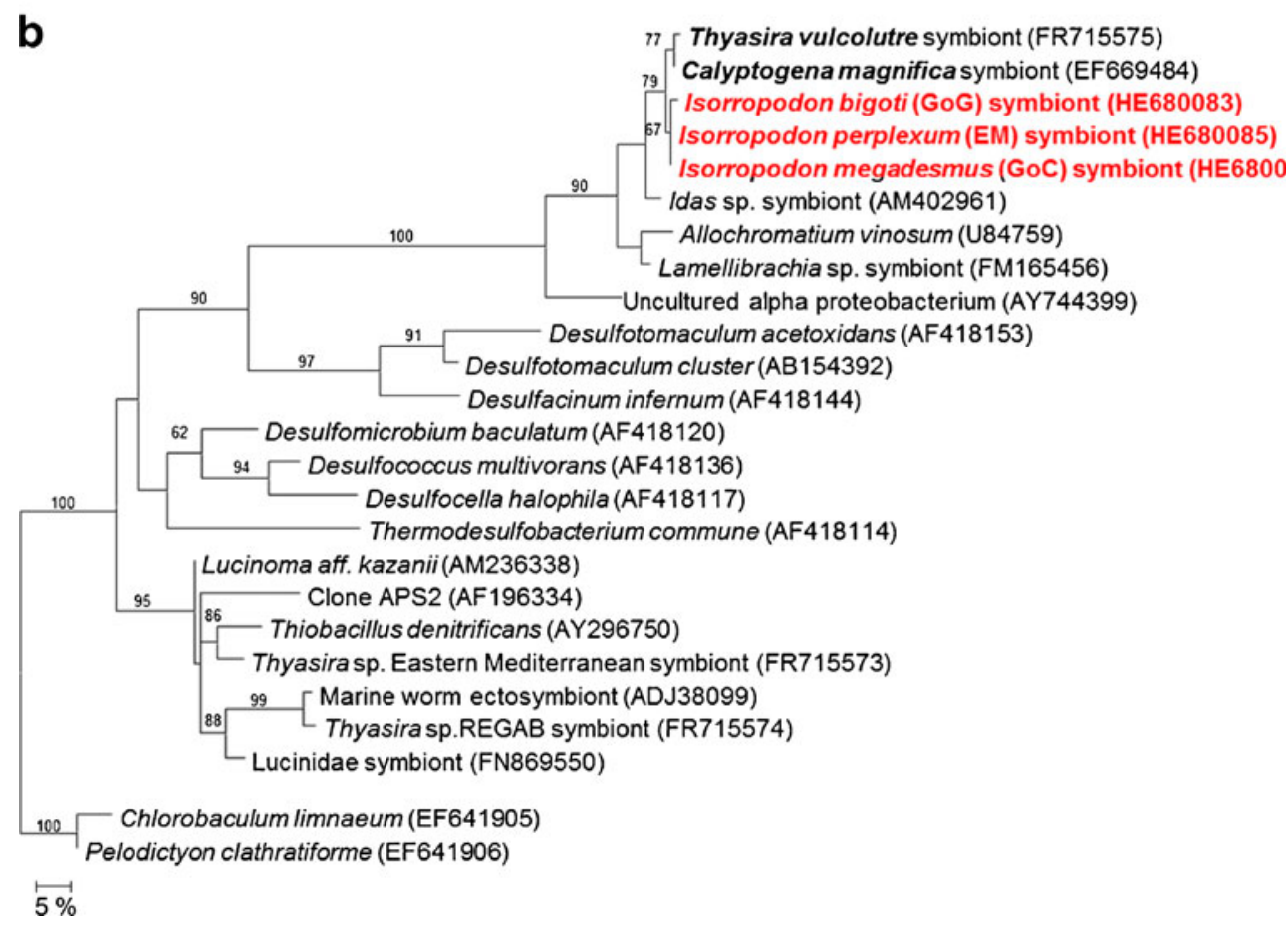

hypothesized that I. perplexum colonized the Mediterranean from Eastern Atlantic ancestors recently. The Strait of Gibraltar may act as an important limitation to connectivity between these two biogeographic regions which may explain the higher genetic divergence of Atlantic vs. Mediterranean species. A different trend is found in the symbionts, with genetic difference between I. perplexum and I. megadesmus symbionts than between Atlantic species. This suggests that symbiont transmission may not be strictly vertical in vesicomyids, and symbiont movement between hosts or acquisition from the environment may contribute to incongruence between host and symbiont phylogenies. Most Isorropodon species were reported from the Atlantic Ocean ( 7 out of 9 species). This geographical distribution, and the wide vertical range (from 150 to $6,809 \mathrm{~m}$ ) (Krylova et al. 2011), in combination with the high level of adaptation to reducing environments, makes Isorropodon a prospective model to study biogeographical, ecological and depth-related evolutionary processes in hosts and symbionts. 
Acknowledgments Thanks are due to the chief-scientists and crew of the several cruises were specimens were collected: TTR17 Leg 2 (Gulf of Cadiz, RV Logatchev): Luis Pinheiro (Departamento de Geociências, Universidade de Aveiro) and Michael Ivanov (Moscow State University); MSM13/4 (Eastern Mediterranean; RV MS Merian, ROV Quest): Antje Boetius and Frank Wenzhofer (Max Planck Insittute); WACS (Gulf of Guinea; RV Pourquoi Pas?, ROV Victor 6000). The authors are indebted to Nelly Leger of the team AMEX (UPMC) for her help in the lab. Finally we are grateful to the two anonymous reviewers and the editor Dr. Charles Fisher for their constructive and helpful comments.

This research was supported by the European Commission Seventh Framework Programme (FP7/2007-2013) under the HERMIONE project contract 226354, French ANR DeepOases, GDRE-DIWOOD and CHEMECO ESF EURODEEP (FCT; EURODEEP/0001/2007). CFR was also supported by a post-doctoral fellowship (SFRH/BPD/64154/ 2009) from the Fundação para a Ciência e a Tecnologia (FCT, Portugal).

\section{References}

Allen JA (2001) The family Kelliellidae (Bivalvia: Heterodonta) from the deep Atlantic and its relationship with the family Vesicomyidae. Zool J Linn Soc-Lond 131:199-226

Altschul SF, Madden TL, Schaeffer AA, Zhang J, Zhang Z, Miller W, Lipman DJ (1997) Gapped BLAST and PSI-BLAST: a new generation of protein database search programs. Nucleic Acids Res 25(17):3389-3402

Amano K, Kiel S (2007) Fossil vesicomyid bivalves from the North Pacific region. Veliger 49:270-293

Baco AR, Smith CR, Peek AS, Roderick GK, Vrijenhoek RC (1999) The phylogenetic relationships of whale-fall vesicomyid clams based on mitochondrial COI DNA sequences. Mar Ecol Prog Ser 182:137-147

Carlier A, Ritt B, Rodrigues CF, Sarrazin J, Olu K, Grall J, Clavier J (2010) Heterogeneous energetic pathways and carbon sources on deep eastern Mediterranean cold seep communities. Mar Biol 157 (11):2545-2565

Cary SC, Giovannoni SJ (1993) Transovarial inheritance of endosymbiotic bacteria in clams inhabiting deep-sea hydrothermal vents and cold seeps. Proc Natl Acad Sci 90:5695-5699

Cole JR, Chai B, Marsh TL, Farris RJ, Wang Q, Kulam SA, Chandra S, McGarrell DM, Schmiedl TM, Garrity GM, Tiedje JM (2003) The Ribosomal Database Project (RDP-II): previewing a new autoaligner that allows regular updates and the new prokaryotic taxonomy. Nucleic Acids Res 31(1):442-443

Cosel RV, Olu K (2009) Large Vesicomyidae (Mollusca: Bivalvia) from cold seeps in the gulf of Guinea off the coasts of Gabon, Congo and northern Angola. Deep-Sea Res II 56:2350-2379

Cosel RV, Salas C (2001) Vesicomyidae (Mollusca: Bivalvia) of the genera Vesicomya, Waisiuconcha, Isorropodon and Callogonia in the eastern Atlantic and the Mediterranean. Sarsia 86(4-5):333366

Decker C, Olu K, Cunha RL, Arnaud-Haond S (2012) Phylogenetic relationships among cold-seep vesicomyid bivalves from the Gulf of Guinea and their western Atlantic and Pacific counterparts. PLoS One 7(4):e33359. doi:10.1371/journal.pone.0033359

Dubilier N, Bergin C, Lott C (2008) Symbiotic diversity in marine animals: the art of harnessing chemosynthesis. Nat Rev Microbiol 5:725-740

Duggen S, Hoernie K, van den Bogaard P, Rupke L, Phipps Morgan J (2003) Deep roots of the Messinian salinity crisis. Nature 422: 602-606
Duperron S, Fiala-Medioni A, Caprais JC, Olu K, Sibuet M (2007) Evidence for chemoautotrophic symbiosis in a Mediterranean cold seep clam (Bivalvia-: Lucinidae): comparative sequence analysis of bacterial 16S rRNA, APS reductase and RubisCO genes. FEMS Microbiol Ecol 59:64-70

Duperron S, Halary S, Lorion J, Sibuet M, Gaill F (2008) Unexpected co-occurrence of six bacterial symbionts in the gills of the cold seep mussel Idas sp. (Bivalvia: Mytilidae). Environ Microbiol 10 (2):433-445

Felsenstein J (1993) PHYLIP (phylogeny inference package) 3.57c edn. Department of Genetics, University of Washington, Seattle

Fisher CR (1990) Chemoautotrophic and methanotrophic symbioses in marine invertebrates. Rev Aquat Sci 2(3,4):399-436

Fujiwara Y, Kojima S, Mizota C, Maki Y, Fukikura K (2000) Phylogenetic characterization of the endosymbionts of the deepestliving vesicomyid clam, Calyptogena fossajaponica, from the Japan Trench. Venus Jap Jour Mal 59(4):307-316

Garcia-Merchan VH, Robainas-Barcia A, Abelló P, Macpherson E, Palero F, Garcia-Rodriguez M, Gil de Sola L, Pascual M (2012) Phylogeographic patterns of decapod crustaceans at the AtlanticMediterranean transition. Mol Phylogenet Evol 62:664-672

Goffredi SK, Hurtado LA, Hallam S, Vrijenhoek RC (2003) Evolutionary relationships of deep-sea vent and cold seep clams (Mollusca: Vesicomyidae) of the "pacifica/lepta" species complex. Mar Biol 142:311-320

Hammer T, Harper DAT, Ryan PD (2001) PAST: paleontological statistics software package for education and data analysis. Palaeontol Electron 4:1-9

Harada M, Yoshida T, Kuwahara H, Shimamura S, Takaki Y, Kato C, Miwa T, Miyake H, Maruyama T (2009) Expression of genes for sulfur oxidation in the intracellular chemoautotrophic symbiont of the deep-sea bivalve Calyptogena okutanii. Extremophiles 13 (6):895-903

Hurtado LA, Mateos M, Lutz RA, Vrinjenhoek RC (2003) Coupling of bacterial endosymbiont and host mitochondrial genomes in the hydrothermal vent clam calyptogena magnifica. Appl Environ Microbiol 69(4):2058-2064

Imhoff JF, Sahling H, Suling J, Kath T (2003) 16S rDNA-based phylogeny of sulphur-oxidising bacterial endosymbionts in marine bivalves from cold-seeps environments. Mar Ecol Prog Ser 249:39-51

Kim Y, Yasuda M, Yamagishi A, Oshima T, Ohta S (1995) Characterization of the endosymbiont of a deep-sea bivalve Calyptogena soyoae. Appl Environ Microbiol 61(2):823-827

Kojima S, Kobayashi T, Hashimoto J, Ohta S (1995) RFLP analysis of a mitochondrial gene, Cytochrome Oxidase I (COI) of three species of the genus Calyptogena around Japan. J Oceanogr $51: 257-259$

Kojima S, Fujikura K, Okutani T (2004) Multiple trans-Pacific migrations of deep-sea vent/seep endemic bivalves in the family Vesicomyidae. Mol Phylogenet Evol 32:396-406

Kojima S, Tsuchida E, Numanami H, Fujikura K, Okutani T (2006) Synonymy of Calyptogena solidissima with Calyptogena kawamurai (Bivalvia: Vesicimyidae) and its popularion structure revealed by mitochondrial DNA sequences. Zool Sci 23:835-842

Krylova EM, Sahling H (2010) Vesicomyidae (Bivalvia): current taxonomy and distribution. PLoS One 5(4):e9957

Krylova EM, Gebruk AY, Portnova DA, Todt C, Haflidason H (2011) New species of the genus Isorropodon (Bivalvia: Vesicomyidae: Pliocardiinae) from cold methane seeps at Nyegga (Norwegian Sea, Voring Plateau, Storrega slide). J Mar Biol Assoc UK 91(5):1135-1144

Kuwahara H, Takaki Y, Yoshida T, Shimamura S, Takishita K, Reimer J, Kato C, Maruyama T (2008) Reductive genome evolution in chemoautotrophic intracellular symbionts of deep-sea Calyptogena clams. Extremophiles 12(3):365-374 
Lane DJ (1991) 16S/(23S rRNA sequencing. In: Stakebrandt E, Goodfellow M (eds) Nucleic acid techniques in bacterial systematics. Wiley, New York, pp 115-175

Meyer B, Kuever J (2007) Molecular analysis of the distribution and phylogeny of dissimilatory adenosine-59-phosphosulfate reductase-encoding genes (aprBA) among sulfuroxidizing prokaryotes. Microbiol 153:3478-3498

Okutani T, Fujikura K, Kojima S (2000) New taxa and review of vesicomyid bivalves collcted from the northwest Pacific by deep-sea research systems of Japan Marine Science \& Technology Center. Venus Jap Jour Mal 59:83-101

Oliver PG, Rodrigues CF, Cunha MR (2011) Chemosymbiotic bivalves from the mud volcanoes of the Gulf of Cadiz, NE Atlantic, with descriptions of new species of Solemyidae, Lucinidae and Vesicomyidae. Zookeys 113:1-38

Olu-Le Roy K, Sibuet M, Fiala-Médioni A, Gofas S, Salas C, Mariotti A, Foucher JP, Woodside J (2004) Cold seep communities in the deep eastern Mediterranean Sea: composition, symbiosis and spatial distribution on mud volcanoes. Deep-Sea Res I 51:1915-1936

Osborn M (2001) Molecular systematics of the vesicomyid clams: Calyptogena kilmeri and Vesicomya gigas. MBARI report. pp 7

Peek AS, Gustafson RG, Lutz RA, Vrijenhoek RC (1997) Evolutionary relationships of deep-sea hydrothermal vent and cold-water clams (Bivalvia: Vesicomyidae) results from the mitochondrial cytochrome oxidase subunit I. Mar Biol 130:151-161

Peek AS, Feldman RA, Lutz RA, Vrijenhoek RC (1998) Cospeciation of chemoautotrophic bacteria and deep-sea clams. Proc Natl Acad Sci 95:9962-9966

Peek AS, Gaut BS, Feldman RA, Barry JP, Kochevar RE, Lutz RA, Vrijenhoek RC (2000) Neutral and Nonneutral Mitochondrial Genetic Variation in Deep-Sea Clams from the Family Vesicomyidae. J Mol Evol 50 (2):141-153
Ronquist F, Huelsenbeck JP (2003) MrBayes 3: Bayesian phylogenetic inference under mixed models. Bioinformatics 19(2):15721574

Stewart FJ, Cavanaugh CM (2009) Pyrosequencing analysis of endosymbiont population structure: co-occurrence of divergent symbiont lineages in a single vesicomyid host clam. Environ Microbiol 11(8):2136-2147

Stewart FJ, Young CR, Cavanaugh CM (2008) Lateral symbiont acquisition in a maternally transmitted chemosynthetic clam endosymbiosis. Mol Biol Evol 25(4):673-687

Stewart FJ, Young CR, Cavanaugh CM (2009) Evidence for homologous recombination in intracellular chemosynthetic clam. Mol Biol Evol 26(6):1391-1404

Sturany R (1896). Zoologische Ergebnisse VII. Mollusken I (Prosobranchier und Opisthobranchier; Scaphopoden; Lamellibranchier) gesammelt von S.M. Schiff "Pola" 1890-1894. Denkschriften der Kaiserlichen Akademie der Wissenschaften, MathematischeNaturwissenschaftlischen Classe 63:1-36, pl.1-2

Taviani M (1994) The "calcari a Lucina" macrofauna reconsidered: deep-sea faunal oases from Miocene-age cold vents in the Romagna Apennine, Italy. Geo-Mar Lett 14:185-191

Thiele J, Jaeckel S (1931) Muscheln der Deutschen Tiefsee Expedition. Wissenschaftliche Ergebnisse der Deutschen Tiefsee Expedition 1898-1899 21:159-268

Thompson JD, Gibson TJ, Plewniak F, Jeanmougin F, Higgins DG (1997) The Clustal X-Windows interface: flexible strategies for multiple sequence alignments aided by quality analysis tools. Nucleic Acids Res 25(24):4876-4882

Zielinski FU, Pernthaler A, Duperron S, Raggi L, Giere O, Borowski C, Dubilier N (2009) Widespread occurrence of an intranuclear bacterial parasite in vent and seep bathymodiolin mussels. Environ Microbiol 11(5):1150-1167 